How to cite: Huțanu, E., Urzică, A., Ghindăoanu, V.B. (2019) Water Parameters Physico-Chemical Variation in the Phreatic Aquifer of Băiceni Locality, Botosani County. 2019 "Air and Water - Components of the Environment" Conference Proceedings, Cluj-Napoca, Romania, p. 207-216, DOI: 10.24193/AWC2019_21.

\title{
WATER PARAMETERS PHYSICO-CHEMICAL VARIATION IN THE PHREATIC AQUIFER OF BĂICENI LOCALITY, BOTOSANI COUNTY
}

\author{
Elena HUT,ANU ${ }^{I}$ 冈, Andrei URZIC $\breve{A}^{I}$, \\ Vasile Bogdan GHIND $\breve{O A N U^{I}}$
}

\section{DOI: 10.24193/AWC2019_21}

\begin{abstract}
Most of the population in the Moldavian Plateau feeds with water from the groundwater, without being analyzed from a qualitative point of view. The present research aims to evaluate the physic-chemical parameters of the water in the Băiceni locality, Botosani County, in order to establish the water quality classes. For this present study, a series of field measurements were carried out during August 6-9, 2014, which determined the depth of the groundwater, the water column in the wells of Băiceni, as well as the physico-chemical parameters (temperature, $\mathrm{pH}$, the dissolved oxygen and the amount of salts) of 52 fountains water samples. Measurements were performed using the Hach Lange Multiparameter. From a qualitative point of view, the water in Băiceni has a $\mathrm{pH}$ between 7.12 and 8.13. Dissolved oxygen varies depending on the depth and location of the well (in a flat or hill area). Dissolved oxygen in flat areas can also reach $0.52 \mathrm{mg} / \mathrm{l}$ in water and decrease with depth. In the hill areas, the dissolved oxygen has higher values, with maximum values of $7.83 \mathrm{mg} / \mathrm{l}$. The total amount of salt varies depending on the type of soil. Higher values were registered in the wells on the slopes of Baiceni Hill (maximum value of $3620 \mathrm{mg} / \mathrm{l})$. The lowest amount of salt was recorded in the northeastern part of the locality, with a value of $483 \mathrm{mg} / \mathrm{l}$.
\end{abstract}

Keywords: pH, dissolved oxygen, water quality, groundwater

\section{INTRODUCTION}

Water has always been the key to life, and it has been used in all areas of human activity. As for human organism, the main source of life is water. That's why its quality is very impressive, depending on the health of man. On the territory of Romania, about one-third of the population feeds with water from the wells, not being connected to the public water supply system. Concerned is the fact that from studies conducted in Romania, a very small percentage of the water in the phreatic is drinking. As far as the Plateau of Moldova is concerned, the percentage is much lower than the national level (Fig. 1).

Considering the great importance of water quality for human and animal life, numerous studies have been conducted on the quality of water in rivers, lakes

\footnotetext{
1 Alexandru Ioan Cuza University of Iasi, Faculty of Geography and Geology, Department of Geography, Bd. Carol I 20A, 700505, Iasi, Romania hutanu.elena@yahoo.com
} 
(Akin, et al., 2010) and underground (Howladar \& Rahman, 2016) areas with high percentage of water pollution as benefits to human health and environment, as well as to implement measures to improve water quality. Studies in the field have been carried out both at national (Romanescu et al., 2014, Romanescu et al., 2015a, Romanescu et al., 2015b, Romanescu et al., 2016, Romanescu et al., 2017, Romanescu et al., 2018, Djari et al., 2018, Mihu-Pintilie et al., 2014, Cruceanu et al., 2015, Cozma et al., 2015, Mihu-Pintilie et al., Mihu-Pintilie et al., 2015) and international levels.

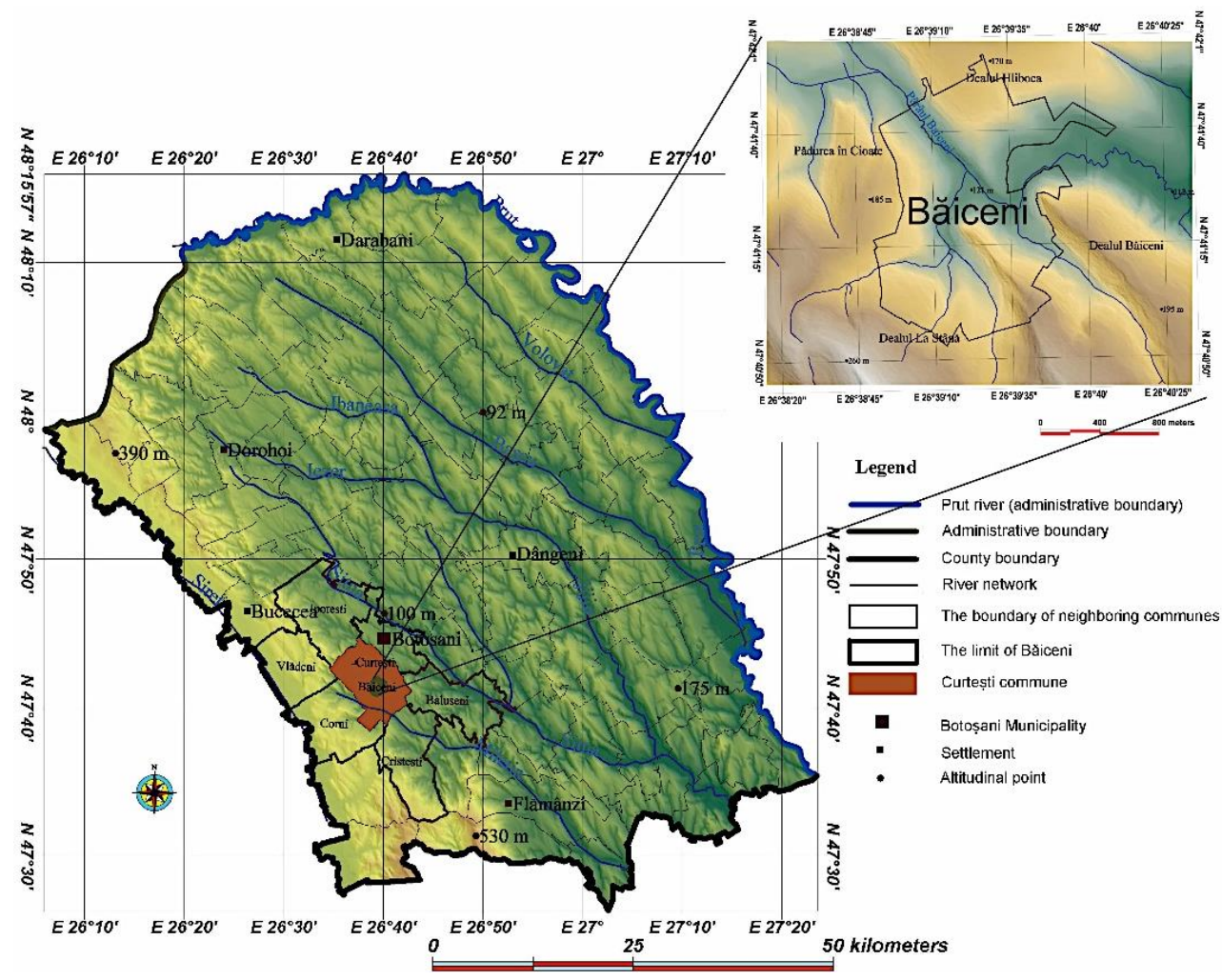

Fig. 1. The geographic position of the study area

As regards the quality of river water in the world, studies have been conducted in the Coruh basin (Turkey), where the contribution of pollutants from domestic, industrial and agricultural activities (Bilgin, 2015) has been highlighted. Also in Turkey, water quality was monitored on the Buyuk Menderez River, analyzing the effect of water pollutants on fish species (Ylmaz \& Koc, 2016). In China, due to the rapid development of the economy and urbanization, more and more water bodies are polluted, eutrophication and damage to the aquatic environment occurring. Thus, research has been done to rehabilitate the aquatic environment of the Yangtze River Basin through the study of the Nanfeihe River, where water rehabilitation has been carried out by planting aquatic species, improving the quality of aquatic life (Wu et al., 2012). For potable water, drinking water studies 
were conducted in Gümüşhane, Turkey, where the physical and geochemical parameters of the water were analyzed, most of the samples taken in the analysis fit into the class of drinking water and for use (Sipahi \& Uslu, 2016).

Given the high percentage of population in Romania that supplies water from wells, the present study aims to assess the water quality of phreatic a resort that is supplied with water from wells. The studied area is the Băiceni locality. This is part of the commune of Curteşti, being located in the central-western part of the Botosani county. It is bordered to the north by the administrative territory of Ipoteşti, northeast of Botosani, southeast territory Băluşeni, in the south of the village Cristesti, in the southwest of the village Horns and northwest territory administrative district of Vlădeni commune (Fig. 1).

From a geomorphologic point of view, Băiceni is part of the large unit of the Moldavian Plateau, the Moldavian Plain Subunit, being located in the Jijia-Bahlui depression area, sub-subunit Jijia-Başeu. The current area of the locality has $171,79 \mathrm{ha}\left(1,71 \mathrm{~km}^{2}\right)$, the total surface studied being of $663,82 \mathrm{ha}\left(6,63 \mathrm{~km}^{2}\right)$, and the population density is $484,71 \mathrm{loc} . / \mathrm{km}^{2}$.

\section{DATA AND METHODS}

\subsection{Data used}

For the study was used data collected by Hach Lange Multiparameter. It consists of three sensors that accept the $\mathrm{pH}$, the dissolved oxygen and the total amount of salts in the water. This data was processed in the TNT Mips SIG software as well as in Microsoft Office Excel.

\subsection{Methods}

In the first phase, a series of field measurements were performed over several periods of the year for data collection. The first field measurements were made to locate the fountains in Băiceni and to determine the fountains to be analyzed. Finally, 37 fountains were studied, depending on their location and the presence of pollution.

The second measurement was carried out in August 6-9, 2014, where the depth of the phreatic, water column in the wells of Băiceni was measured, as well as water parameters: $\mathrm{pH}$, the dissolved oxygen and the amount of salts present in the wells water. Water analysis was performed on the ground by introducing sensors into the wells. Measurements were made at each well, with the first measure being at the gloss of water, followed by those in the meter to the sediment.

With the obtained results, the map of the water depth from the phreatic water as well as the column of water from the fountains was made. These were achieved by interpolation of the points obtained from the measurements. The second step was to analyse the distribution of physico-chemical parameters of water and to identify the factors that led to those values. 


\section{RESULTS AND DISCUSSIONS}

To assess the depth of water in the phreatic, measurements were made at 37 wells during three days, namely August 7, 8 and 9, 2014. During this time, both $\mathrm{pH}$, dissolved oxygen, and amount of salts present in the water were measured.

As a result of the measurements, the volume of usable water from the phreatic water that arrived was calculated at $516,42 \mathrm{~m}^{3}$. This volume represents approximately one-third of the total water volume usable in all studied area which includes approximately 150-170 wells.

In the Băiceni locality, the water is found in the phreatic depths at half a meter deep, in the northwest of the town, where there is a flat area with surface springs, the depth of the remaining areas ranging between 1 and 2 meters. The maximum depths of water from the phreatic are reached in the north of the locality, where values between 15 and 20 meters have been recorded (Fig. 2).

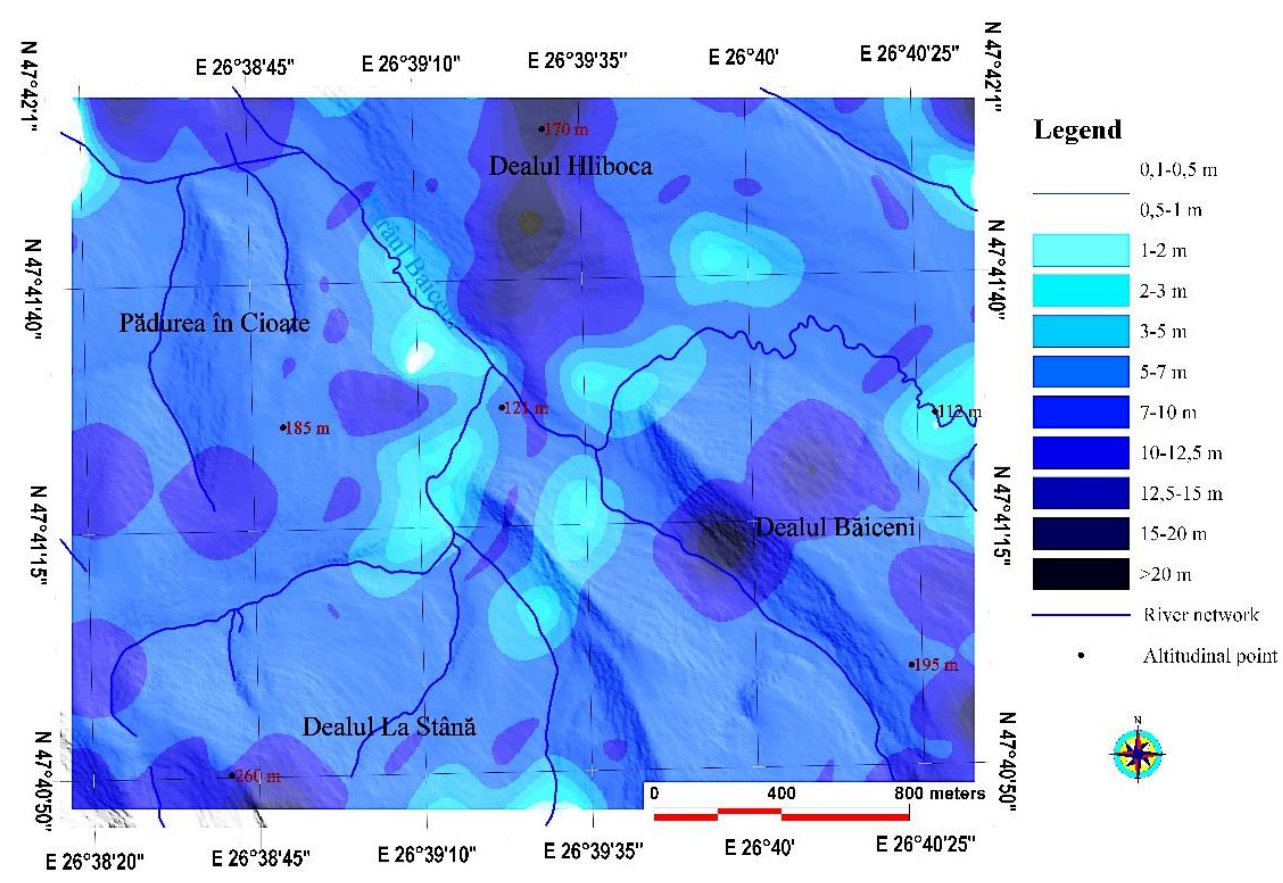

Fig. 2. Phreatic water depth map of the Băiceni locality

The depth of the water column maintains the same distribution as the depth of water. This is probably due to the fact that in the hill areas the water is at high depths, and the locals have drifted deeper depending on the water level at the time of the drilling and to prevent the drainage of the wells (Fig. 3).

The most frequent occurrences are those in which only $1 \mathrm{~m}$ or $2 \mathrm{~m}$ bore from the point where water is found in the phreatic, which leads to the drainage of the wells in the drought seasons. Therefore, although the water in the phreatic is found 
at lower depths in the areas, there is also a smaller column of water (about $2 \mathrm{~m}$ ), which makes the groundwater recession in the drought seasons.

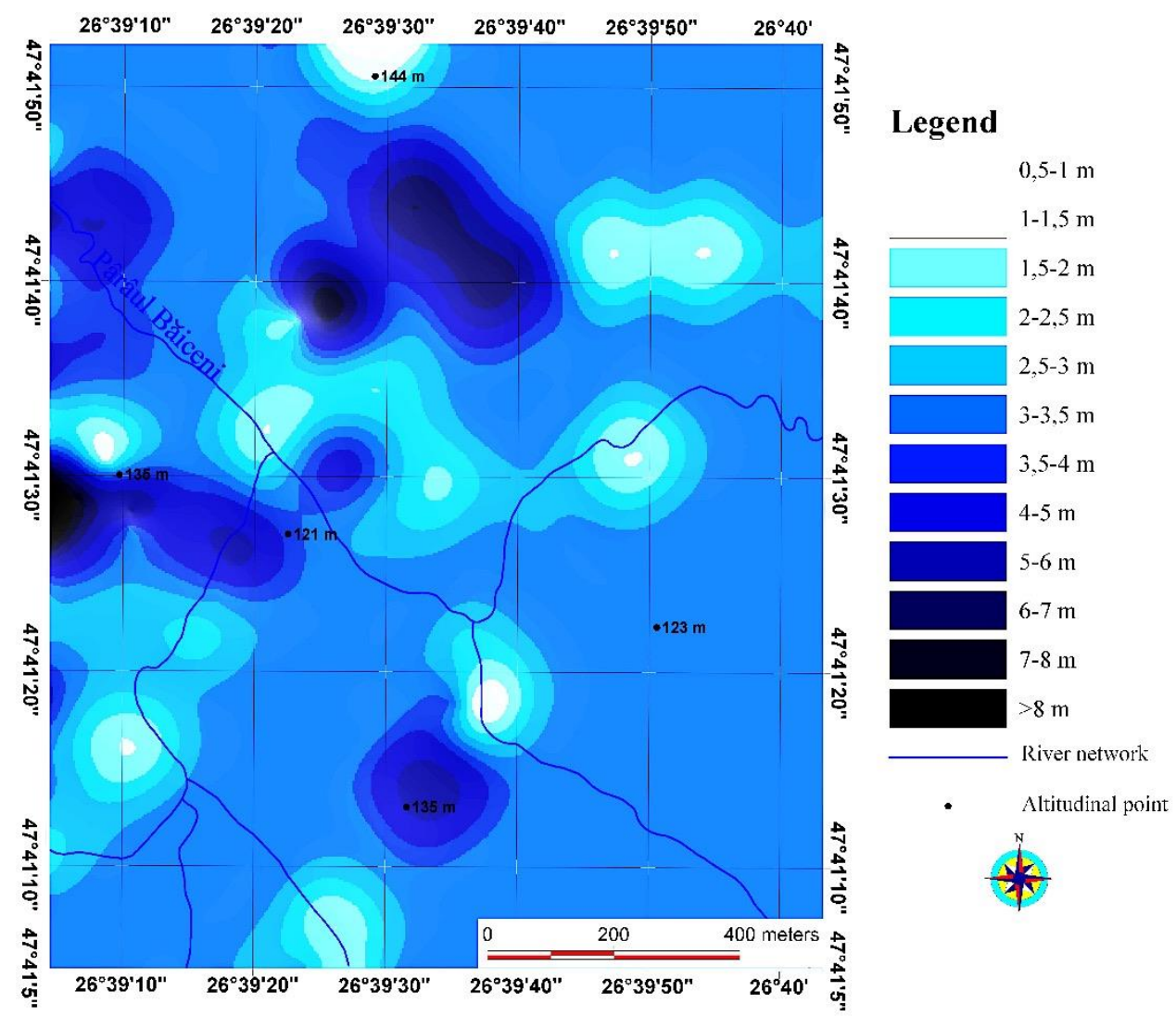

Fig. 3. Map of the water column usable for the Băiceni locality

Figure 4 shows the location of the studied wells. Their distribution is uniform throughout the area, a factor taken into account to make a complete analysis.

From the point of view of the quality of the water in the area Băiceni shows a $\mathrm{pH}$ of between 6.30 and 8.70, the most common values being between 7 and 7.5 (Fig. 5). The value of 6.3 is recorded in the well 36 which is located upstream of a landfill.

The highest $\mathrm{pH}$ values are recorded at the well 28 , where the $\mathrm{pH}$ values range from 7.39 to 7.42 , with values of 12.6 for the sediment (at the bottom of the well) where a 30 lime rolls to reduce the salty taste of water. As a result of the analyzes it is found that out of all the surrounding wells, the fountain 28 has a salty taste, which has a much lower amount of salt compared to the others.

Dissolved oxygen varies between each well from water to sediment and depending on the location of the fountain, in a flat or hill area. Thus, in the plain areas, the dissolved oxygen can reach values of $0.52 \mathrm{mg} / \mathrm{l}$ at the water surface, it 
decreasing with the depth. In the hill areas, the dissolved oxygen is slightly higher, the maximum value being $7.83 \mathrm{mg} / \mathrm{l}$ (Fig. 6).

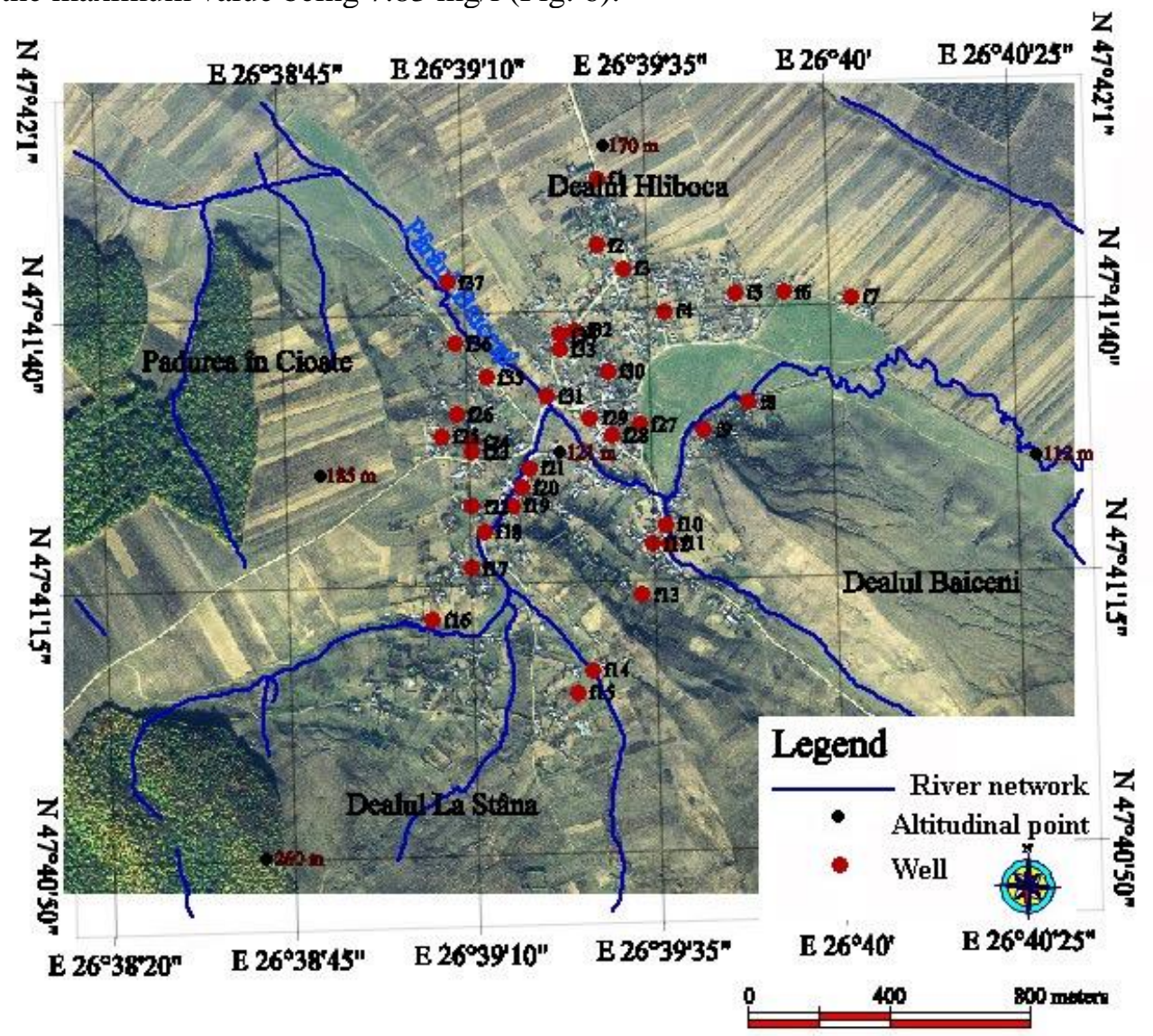

Fig. 4. Map location of the wells studied the Băiceni locality

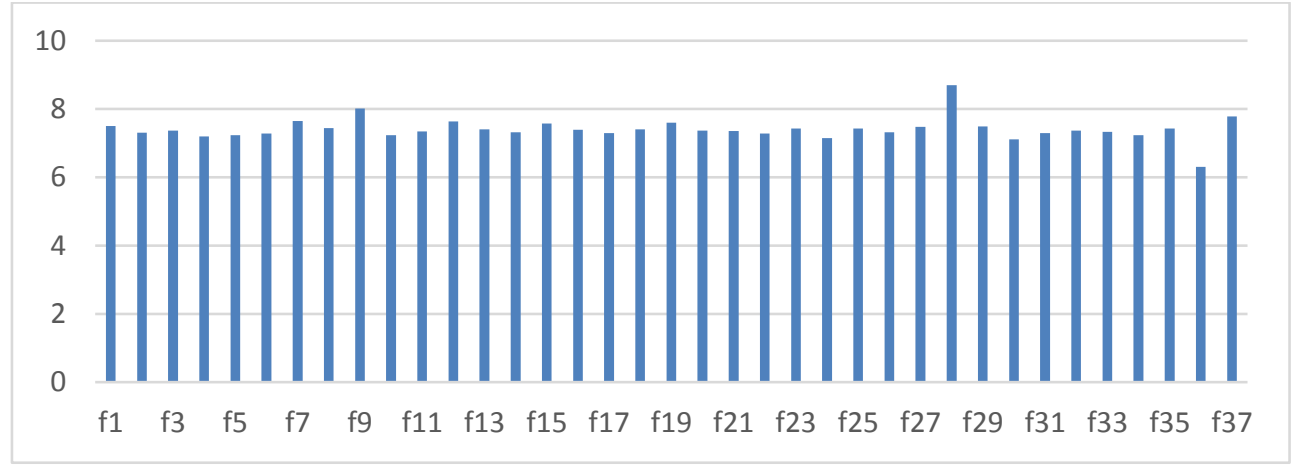

Fig. 5. The graphical representation of the pH values in the wells studied in Băiceni locality 
The lowest values of dissolved oxygen are recorded at wells where water is present at low depths, but also in wells with a low water volume. Referring to the dissolved oxygen at the water column in the wells, we notice a gradual decrease from the gloss of water to sediment. Almost 50\% of wells studied have a level of dissolved oxygen below $2 \mathrm{mg} / \mathrm{l}$. The reduced amount of dissolved oxygen results in the presence of large numbers of micro-organisms, indicating a high risk of the population in the case of water consumption.

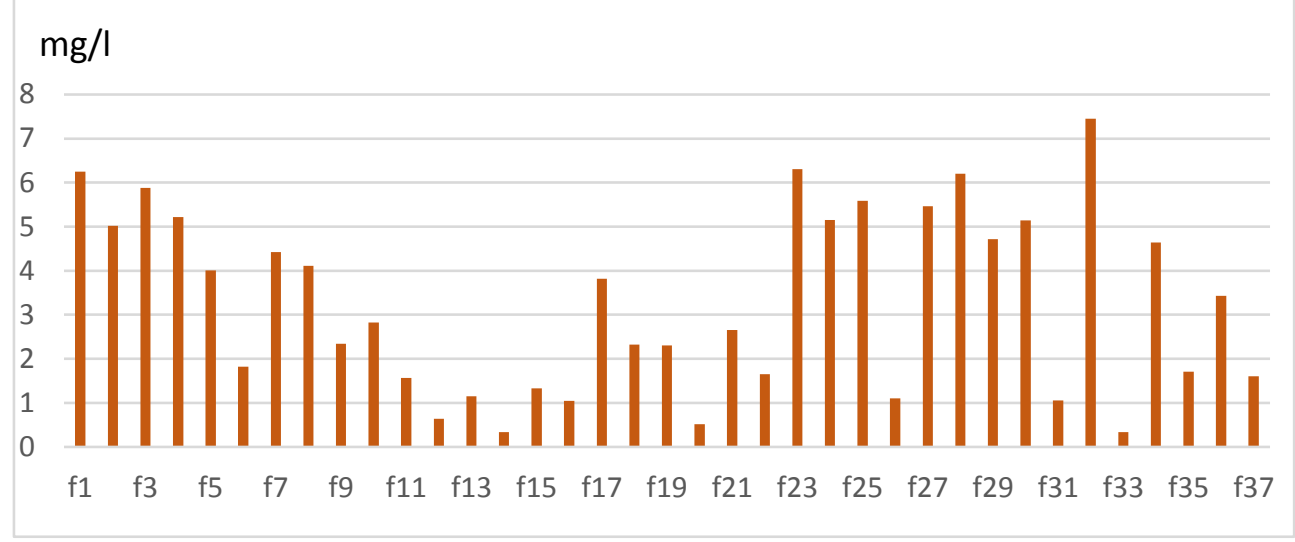

Fig.6. The graphical representation of the dissolved oxygen values from the water wells studied in Băiceni locality

The total quantity of salts varies according to the type of soil, with higher values recorded in the wells of the slopes of the Băiceni Hill. The high amount of salt in the same area could indicate the presence of a salt deposit. This results in $3550 \mathrm{mg} / \mathrm{l}$ in the same well, but at $2.5 \mathrm{~m}$ it reaches a value of $3620 \mathrm{mg} / \mathrm{l}$. This water cannot be used for household purposes either.

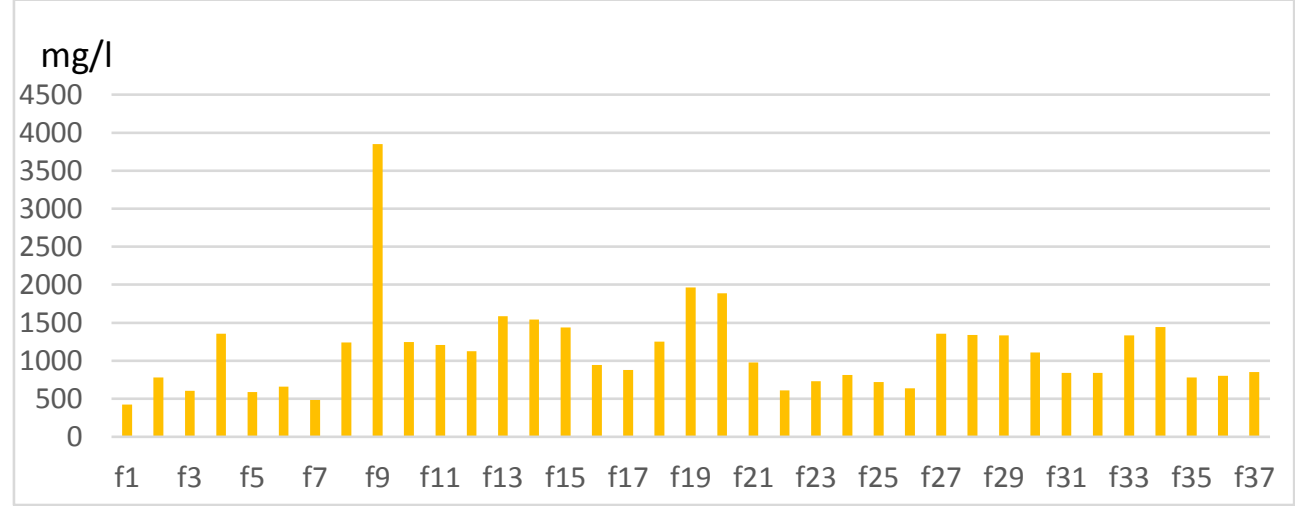

Fig. 7. The graphical representation of the total amount of salts present in the water of the fountains studied in Băiceni locality 
The lowest amount of salt was recorded in the northeastern part of the city, with a value of $483 \mathrm{mg} / \mathrm{l}$. Over $50 \%$ of the well water studied has values below $1000 \mathrm{mg} / \mathrm{l}$ salts.

\section{CONCLUSIONS}

Following the study carried out in Băiceni, the presence of water is identified in low water phreatic conditions, which makes water a risk of disease in where it is consumed by humans because it takes up very much easily all polluting substances from human activities. Relating only the analyzed parameters, out of the 37 fountains studied, only two of them could be considered as first quality, followed by second quality ones, the largest share being held by wells containing nonpotable water (about $60 \%$ ) on the road, the water being at low depths.

\section{REFERENCES}

1. Akin B. S., Atıc1 T., Katircioglu H., Keskin F. (2010), Investigation of water quality on Go"kc, ekaya dam lake using multivariate statistical analysis, in Eskis, ehir, Turkey. Environmental Earth Science, 63, 1251-1261. DOI 10.1007/s12665-0100798-6.

2. Bilgin A. (2015), An assessment of water quality in the Coruh Basin (Turkey) using multivariate statistical techniques. Environmental monitoring and assessment, 187(721). DOI 10.1007/s10661-015-4904-9.

3. Cozma D. G., Cruceanu A., Cojoc G. M., Mihu-Pintilie A., Muntele I. (2015), The factorial analysis of physico-chemical indicators in Bistrita's upper hydrographic basin. In: SGEM - Hydrology and Water Resources, Conferences Proceedings, Albena. ISSN 1314-2704, WOS:000371663400080.

4. Cruceanu A., Cojoc G. M., Cozma D. G., Muntele I., Mihu-Pintilie A. (2015), Comparativ study of surface waters quality in the hydrographic upper basin of Bistrita river (Romania). In: SGEM - Hydrology and Water Resources, Conferences Proceedings, Albena. ISSN 1314-2704, WOS:000371663400021.

5. Djari M.M.S., Stoleriu C.C., Saley M.B., Mihu-Pintilie A., Romanescu G. (2018), Groundwater quality analysis in warm semi-arid climate from Sahel countries: Tillabéri Region, Niger. Carpathian Journal of Earth and Environmental Sciences, B.M., 13(1): 277 - 290. https://doi.org/10.26471/cjees/2018/013/024.

6. Howladar M. F., Rahman Md. M. (2016), Characterization of underground tunnel water hydrochemical system and uses through multivariate statistical methods: a case study from Maddhapara Granite Mine, Dinajpur, Bangladesh. Environmental Earth Science. DOI 10.1007/s12665-016-6309-7.

7. Mihu-Pintilie A., Romanescu G., Stoleriu C. C., Breaban I. G. (2015), PhysicoChemical Parameters in Mountain Freshwater: Cuejdi River from Eastern Carpathians, Romania. Key Engineering Materials, 660: 257-261.

8. Mihu-Pintilie A., Romanescu G., Stoleriu C. C. (2014)a, The seasonal changes of the temperature, $\mathrm{pH}$ and dissolved oxygen in the Cuejdel Lake, Romania. 
Carpathian Journal of Earth and Environmental Sciences, B.M., 9(2): 113-23. WOS:000334903200011.

9. Mihu-Pintilie A., Paiu M., Breabăn I. G., Romanescu G. (2014)b, Status of water quality in Cuejdi hydrographic basin from Eastern Carpathian, Romania. In: SGEM - Hydrology and Water Resources, Conferences Proceedings, Albena, 14(1): 639646. https://doi.org/10.5593/sgem2014B31.

10. Romanescu G., Mihu-Pintilie A., Trifanov C., Stoleriu C.C. (2018), The variations of physico-chemical parameters during summer in Lake Erenciuc from the Danube Delta (Romania). Limnological Review, 18(1): 21-29. https://doi.org/10.2478/limre-2018-0003.

11. Romanescu G., Pascal M., Mihu-Pintilie A., Stoleriu C. C., Sandu I., Moisii M. (2017), Water Quality Analysis in Wetlands Freshwater: Common Floodplain of Jijia-Prut Rivers. Rev. Chim. (Bucharest), 68(3): 553-561. WOS:000400731900029.

12. Romanescu G., Miftode D., Mihu-Pintilie A., Stoleriu C. C., Sandu I. (2016), Water Quality Analysis in Mountain Freshwater: Poiana Uzului Reservoir in the Eastern Carpathians. Rev. Chim. (Bucharest), 67(11): 2318-2326. WOS:000388361900041.

13. Romanescu G., Tirnovan A., Sandu I., Cojoc G. M., Breaban I. G., Mihu-Pintilie A. (2015a), Water Chemism Within the Settling Pond of Valea Straja and the Quality of the Suha Water Body (Eastern Carpathians). Revista de Chimie, Bucharest, 66(10): 1700-1706, WOS:000368436300033.

14. Romanescu G., Cojoc G. M., Sandu I. G., Tirnovan A., Dascalita D., Sandu I. (2015 b), Pollution Sources and Water Quality in the Bistripa Catchment (Eastern Carpathians), Revista de Chimie, Bucharest, 66(6).

15. Romanescu G., Tarnovan A., Sandu I. G., Cojoc G. M., Dascalita D., Sandu I. (2014), The Quality of Surface Waters in the Suha Hydrographic Basin (Oriental Carpathian Mountains). Revista de Chimie, Bucharest, 65(10).

16. Sipahi F., Uslu S. (2016) Investigation of the quality and physical-geochemical characteristics of the drinking water in Gümüşhane (Turkey) city central. Arabian Journal of Geosciences. DOI 10.1007/s12517-016-2620-6.

17. Wu J., Cheng S., Li Z., Guo W., Zhong F., Yin D. (2012), Case study on rehabilitation of a polluted urban water body in Yangtze River Basin. Environmental Science and Pollution Research, 20, 7038-7045. DOI 10.1007/s11356-012-1351-9.

18. Yılmaz E., Koç C. (2016), Organic pollution of the Büyük Menderes River, Turkey and effects on aquaculture. Environmental Science and Pollution Research, 23, 11493-11506. DOI 10.1007/s11356-016-6397-7. 
